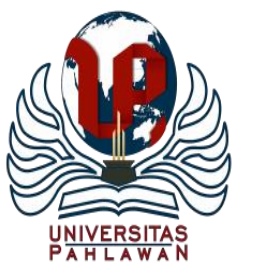

Jurnal Basicedu Volume 4 Nomor 4 Tahun 2020 Halm. 838 - 847

JURNAL BASICEDU

Research \& Learning in Elementary Education

https://jbasic.org/index.php/basicedu/index

\title{
Pengembangan Bahan Ajar Keterampilan Menulis Narasi Dengan Menggunakan Mind Mapping Dalam Pembelajaran Tematik Di Sekolah Dasar
}

\author{
Eliyanti $^{1}$, Taufina ${ }^{2}$, Ramalis Hakim ${ }^{3}$ \\ Universitas Negeri Padang, Sumatera Barat, Indonesia ${ }^{1,2,3}$ \\ E-mail: yantieliyanti25@gmail.com ${ }^{1}$ taufina@ fip.unp.ac.id ${ }^{2}$ ramalishakim@gmail.com ${ }^{3}$
}

\begin{abstract}
Abstrak
Salah satu bentuk keterampilan yang harus dimiliki oleh peserta didik adalah keterampilan menulis. Namun, pada saat ini keterampilan menulis peserta didik sangat rendah. Salah satu penyebab rendahnya keterampilan menulis peserta didik adalah bahan ajar yang digunakan masih minim. Materi yang akan diajarkan kepada peserta didik sebelum semuanya tercakup dalam bahan ajar. Untuk mengatasi demikian perlu adanya pembuatan bahan ajar yang oleh guru sesuai dengan kebutuhan peserta didik dan dibantu dengan teknik yang dapat digunakan oleh guru dalam proses pembelajaran. Teknik yang sesuai untuk keterampilan menulis peserta didik adalah teknik mind mapping. Teknik mind mapping adalah teknik yang terdiri atas pola-pola pemikiran dan kemudian dikembangkan kedalam bentuk tulisan narasi. Penelitian ini dilakukan di kelas V SDN 04 Lembah Melintang Kabupaten Pasaman Barat. Pada awal penelitian dilakukan observasi untuk melihat kondisi awal sebelum digunakan bahan ajar yang didesain guru dengan menggunakan teknik mind mapping.
\end{abstract}

Kata kunci : bahan ajar, mind mapping, keterampilan menulis

\begin{abstract}
One form of skills that must be possessed by students is writing skills. However, at this time students' writing skills are very low. One of the causes of students' writing skills is the lack of teaching materials used are still minimal. The material to be taught to students before all are covered in teaching materials. To overcome this, it is necessary to make teaching materials by teachers in accordance with the needs of students and assisted with techniques that can be used by teachers in the learning process. The appropriate technique for students' writing skills is the mind mapping technique. Mind mapping technique is a technique that consists of patterns of thought and then developed into narrative writing. This research was conducted in class V SDN 04 Lembah Melintang Pasaman Barat District. At the beginning of the study observations were made to see the initial conditions before teaching materials were designed which were designed by the teacher using mind mapping techniques.
\end{abstract}

Keyword : material describe, mind mapping, writing skills

Copyright (c) 2020 Eliyanti, Taufina, Ramalis Hakim

Corresponding author :

Address :

Email : yantieliyanti25@gmail.com

ISSN 2580-3735 (Media Cetak)

Phone :

ISSN 2580-1147 (Media Online)

DOI: $10.31004 /$ basicedu.v4i4.439 


\section{PENDAHULUAN}

Pembelajaran Bahasa Indonesia di SD memuat empat keterampilan berbahasa, yaitu menyimak, berbicara, membaca, dan menulis. Keempat keterampilan itu perlu diberikan titik terang proses pembelajaran yang jelas dan terstruktur agar dapat tercapai secara maksimal. Di antara keempat keterampilan yang diungkapkan, yang menjadi salah satu sorotan utama adalah keterampilan menulis. Menurut Hedge dalam Nurhayati (2008:113) "keterampilan menulis pada dasarnya diperlukan oleh peserta didik karena peserta didik membutuhkannya baik bagi pendidikannya, kehidupan sosialnya, maupun pada kehidupan profesionalnya nanti."

Pembelajaran keterampilan menulis siswa perlu dipupuk sejak awal karena akan bermanfaat nantinya bagi siswa dalam kehidupannya. Pembelajaran menulis hendaknya diarahkan pada pembelajaran yang bersifat aktif, kreatif, menyenangkan, dan mengarahkan siswa pada pengembangan nilai-nilai kehidupan sehingga terwujud sebuah produk yang melalui proses dan mempunyai hasil yang bernilai.

Jenis keterampilan menulis yang harus dikuasai peserta didik di SD salah satunya adalah keterampilan menulis narasi. Saddhono (2012) menjelaskan narasi (penceritaan atau pengisahan) merupakan ragam wacana yang menceritakan proses kejadian suatu peristiwa. Meningkatkan pembelajaran keterampilan menulis narasi dapat dilakukan dengan mengembangkan bahan ajar agar dapat membantu guru dalam melaksanakan kegiatan pembelajaran. Sagala (2009: 23) menjelaskan salah satu kompetensi profesionalisme yang harus dimiliki guru adalah mampu menyusun bahan ajar yang berkualitas sesuai dengan kompetensi, kompetensi dasar, dan bahan ajar yang sesuai dengan kebutuhan dan karakteristik peserta didik.

Depdiknas (2008) menjelaskan bahan ajar berfungsi sebagai (1) pedoman bagi guru yang akan mengarahkan semua aktivitasnya dalam proses pembelajaran, sekaligus sebagai substansi kompetensi yang harus diajarkan kepada peserta didik, (2) pedoman bagi peserta didik yang akan mengarahkan semua aktivitasnya dalam proses pembelajaran dan merupakan substansi kompetensi yang harus dikuasai, dan (3) sebagai alat evaluasi pencapaian hasil pembelajaran.

Menurut Taufina (2020) Guru memiliki tugas merencanakan, melaksanakan, dan mengevaluasi proses pembelajaran. Proses pembelajaran tersebut tidak terlepas dari pentingnya peran bahan ajar. Guru harus mampu mengembangkan bahan ajar dari pemerintah sebagai penunjang keberhasilan penerapan kurikulum 2013. Pengembangan bahan ajar sangatlah diperlukan untuk membantu guru maupun siswa. Sehingga, guru hendaknya mampu memfasilitasi dengan baik proses tersebut sesuai kebutuhan siswanya. Salah satu kebutuhan siswa adalah fasilitas berupa bahan ajar.

Berdasarkan pendapat di atas disimpulkan bahwa bahan ajar yang baik dan ideal adalah bahan ajar yang sesuai dengan kompetensi yang berlaku dan sesuai dengan kebutuhan dan karakteristik peserta didik untuk pencapaian hasil pembelajaran yang efektif. Oleh sebab itu sebelum mengembangkan bahan ajar dipilih teknik pembelajaran yang sesuai. 
Tujuan dari suatu proses pembelajaran adalah untuk meningkatkan dan mencapai suatu peningkatan prestasi. Pencapaian tersebut dapat dilakukan melalui peran aktif atau partisipasi guru dan peserta didik dalam proses pembelajaran. Penerapannya dilakukan dengan memperhatikan aspek perkembangan intelektual, sosial, dan emosional peserta didik, serta penunjang keberhasilan dalam mempelajari semua mata pelajaran. Pembelajaran bahasa diharapkan membantu peserta didik mengenal dirinya, budayanya, dan budaya orang lain. Di samping itu, pembelajaran bahasa Indonesia juga sebagai alat untuk mengemukakan gagasan dan perasaan berpatisipasi dalam masyarakat yang menggunakan kemampuan analitis dan imajinatif yang ada dalam dirinya.

Permasalahan di atas dapat diatasi oleh guru dengan cara mengembangkan bahan ajar menulis narasi secara efektif dan kreatif dengan menggunakan strategi menulis yang tepat yang sesuai dengan karakteristik peserta didik karena dalam Peraturan Menteri Pendidikan dan Kebudayaan Nomor 24 Tahun 2016, kompetensi inti dan kompetensi dasar dapat digunakan sebagai dasar untuk perubahan buku teks pelajaran pada pendidikan dasar dan pendidikan menengah.

Menurut Maistika dan Taufina (2019) salah satu yang diperhatikan dalam pengembangan bahan ajar adalah bahasa indonesia. Dalam kurikulum 2013 bahasa indonesia salah satu aspek dalam proses pembelajaran terutama dalam membaca, hal ini hal ini terkait dengan proses pembelajaran dengan penggunaan bahan ajar yang sesuai dengan tuntutan kurikulum dengan mempertimbangkan kebutuhan peserta didik, yakni bahan ajar yang sesuai dengan karakteristik dan lingkungan sosial peserta didik khususnya bahasa indonesia dalam proses membaca.

Jelaslah bahwa bahan ajar dapat dikembangkan sesuai kompetensi inti dan kompetensi dasar yang diharapkan yaitu dengan mengembangkan bahan ajar menulis narasi menggunakan teknik mind mapping dalam pembelajaran tematik. Penulis mengembangkan bahan ajar keterampilan menulis dengan menggunakan mind mapping karena menurut Buzan (2009:4), mind mapping adalah cara termudah untuk menempatkan informasi ke dalam otak dan mengambil informasi keluar dari otak, mind mapping juga cara mencatat yang kreatif, efektif, dan secara harfiah akan memetakan pikiran-pikiran kita.

Pembelajaran dengan teknik mind mapping mempunyai kelebihan yang dapat membantu peserta didik untuk melihat hubungan antara satu ide dengan ide lainnya. Hal ini seperti yang diungkapkan oleh Taufik dan Muhammadi (2011:176) yang menyatakan bahwa, Ada beberapa kelebihan dengan menggunakan teknik mind mapping yaitu: (1) cara ini cepat, (2) dapat digunakan untuk mengorganisasikan ide-ide yang muncul di kepala, (3) proses menggambar diagram bisa dimunculkan ide-ide yang lain, dan (4) diagram yang sudah terbentuk bisa menjadi panduan untuk menulis.

Selanjutnya langkah-langkah membuat mind mapping juga dapat meningkatkan kreatifitas peserta didik. Menurut Buzan (2009) terdapat tujuh langkah dalam membuat mind mapping yaitu: (1) mulailah 
dari bagian tengah kertas kosong yang sisi panjangnya diletakkan mendatar, (2) gunakan gambar atau foto untuk ide sentral, (3) gunakan warna, (4) hubungkan gambar-gambar utama ke gambar pusat dan hubungkan cabang-cabang tingkat dua dan tiga ke tingkat satu dan dua, dan seterusnya, (5) buatlah garis hubung yang melengkung, (6) gunakan satu kata kunci untuk setiap garis, (7) gunakan gambar.

Warna yang beragam dalam mind mapping juga akan menumbuhkan minat belajar peserta didik untuk menulis. Karena sesuai dengan karakteristik peserta didik pada tahap operasional konkret senang dengan menggambar, menghasilkan karya, dan menulis. Hal ini sesuai dengan yang disampaikan oleh Allen (2008:206) bahwa peserta didik usia 1112 tahun berkonsentrasi dalam melakukan usaha untuk meningkatkan kemampuan motorik halus melalui berbagai aktivitas karena motorik kasarnya telah sempurna.

\section{METODE}

Jenis penelitian ini merupakan penelitian pengembangan (Research and Development). Penelitian pengembangan merupakan penelitian yang dirancang secara terstruktur dan sistematik untuk mengembangkan suatu produk melalui tahapan dan evaluasi tertentu untuk menguji tingkat kevalidan dan keefektifan dalam menggunakannya. Produk yang dihasilkan dalam penelitian pengembangan berbeda dengan pengembangan yang dimaksudkan secara sederhana. Pengembangan sederhana hanya dirancang secara sederhana tanpa ada revisi sebagai masukan dari berbagai ahli. Hal ini berdampak pada tingkat validitas dan efektivitas produk yang dihasilkan kurang dirasakan dalam penggunaannya.

Menyikapi penjelasan di atas, Seels dan Richey (dalam Setyosari, 2010:195) dengan ini menjelaskan bahwa, "Depelopmental research, as opposed to simple instructional development, has been defined as "the systematic study of designing, developing, and evaluating instructional programs, processes and products that must meet the criteria of internal consistency and effectiveness." Artinya, penelitian pengembangan sebagaimana dibedakan dengan pengembangan pembelajaran yang sederhana, didefinisikan sebagai kajian secara sistematik untuk merancang, mengembangkan, dan mengevaluasi program-program, proses, dan hasilhasil pembelajaran yang harus memenuhi kriteria konsistensi dan keefektifan secara internal. Dengan demikian, dalam pengembangannya dilakukan dengan menggunakan model pengembangan.

Prosedur pengembangan ini sesuai dengan tahapan model pengembangan 4-D. Kegiatan pengembangan ini diawali dengan menganalisis kurikulum, merancang bahan ajar dan mengikuti langkah-langkah sesuai dengan tahapan pada model pengembangan 4-D. Adapun langkah-langkah rancangan pengembangan bahan ajar dengan model 4-D yaitu tahap Pendefinian (define), tahap Perancangan (design), tahap pengembangan (develop), dan tahap Penyebaran (disseminate).

Berdasarkan fakta tersebut maka apabila kita juga menyimpan informasi seperti cara kerja otak, maka akan semakin baik informasi tersimpan di dalam otak dan hasil akhirnya tentu saja proses belajar kita akan semakin mudah. Dalam peta pikiran kita dapat melihat hubungan antara ide 
dengan ide lainnya dengan tetap memahami konteksnya.

Menurut Buzan (2009:4) “Teknik Mind Mapping atau peta pikiran adalah cara termudah untuk menempatkan informasi ke dalam otak dan mengambil informasi ke luar otak. Peta pikiran juga merupakan cara mencatat yang kreatif, efektikf, dan secara harafiah akan "memetakan" pikiran-pikiran kita".

Selanjutnya menurut Buzan (2008:11) "Teknik Mind Maping adalah diagram istimewa yang cara kerjanya sesuai dengan cara kerja otak dan membantumu untuk berfikir, membayangkan, mengingat, dan merencanakan serta memilah informasi singkatnya, Mind Maping adalah alat sempurna untuk membantumu belajar dan mengulang pelajaran".

Taufik dan Muhammadi (2011:175) menyimpulkan bahwa "Teknik Mind Mapping adalah satu teknik mencatat yang mengembangkan gaya belajar visual. Teknik Mind Mapping memadukan dan mengembangkan potensi kerja otak yang terdapat di dalam diri seseorang, dengan adanya keterlibatan kedua belah otak, maka akan memudahkan seseorang untuk mengatur dan mengingat segala bentuk informasi, baik secara tertulis maupun secara verbal".

Berdasarkan beberapa pendapat tersebut dapat disimpulkan bahwa Teknik Mind Mapping adalah sebuah cara kerja yang sangat efektif dalam menyampaikan informasi kedalam otak dengan cara membuat garis besar tentang gagasan pokok dari suatu tema dan membuatkan hubungan dengan tema turunan sehingga bisa dipahami dan dimengerti dengan mudah.
Bahan ajar sering disebut sebagai materi pelajaran yang terdiri dari pengetahuan, keterampilan, dan sikap yang dipelajari peserta didik dalam rangka mencapai standar kopetensi yang telah ditentukan. Menurut Abidin (2012:263) "Bahan ajar merupakan suatu program yang disusun guru untuk mengembangkan pengetahuan, keterampilan, dan sikap positif terhadap pembelajaran yang diturunkan dari kurikulum yang berlaku".

Menurut Daryanto dan Dwicahyono (2014: 171) bahwa "Bahan ajar adalah seperangkat materi yang disusun secara sistematis baik tertulis maupun tidak sehingga tercipta lingkungan atau suasana yang memungkinkan peserta didik untuk belajar". Selanjutnya menurut Prastowo (2014: 138), bahan ajar merupakan segala bahan (baik itu informasi, alat, maupun teks) yang disusun secara sistematis yang menampilkan sosok utuh dari kompetensi yang akan dikuasai peserta didik dan digunakan dalam proses pembelajaran dengan tujuan untuk merencanakan dan menelaah implementasi pembelajaran.

Berdasarkan pendapat ahli di atas dapat disimpulkan bahwa bahan ajar merupakan seperangkat materi yang disusun secara sistematis dalam rangka pencapaian standar kompetensi pembelajaran dalam satuan pendidikan.

Bahan ajar memiliki komponen-komponen tertentu yang saling terkait satu sama lain. Seperti yang diterangkan oleh Hamdani (2011:122) yaitu beberapa komponen yang terdapat pada suatu bahan ajar di antaranya:a) judul, mata pelajaran, standar kompetensi, kompetensi dasar, indikator, dan tujuan pembelajaran. b) petunjuk belajar (petunjuk peserta didik dan guru), berisi tentang penjelasan cara 
penggunaan suatu bahan ajar yang akan dipelajari dalam sebuah proses pembelajaran. c) informasi pendukung. d) lembar kerja. f) evaluasi.

Abdul (2006:174) juga mengemukakan "sebuah bahan ajar paling tidak mencakup antara lain: 1) Kompetensi yang akan dicapai, 2) petunjuk belajar ( petunjuk guru dan peserta didik), informasi pendukung, dan evaluasi”. Sedangkan menurut Mujiyono (2014:3) menjelaskanbahwa komponen bahan ajar terdiri atas (1) identitas mata pelajaran, meliputi judul, materi, kompetensi, indikator, tujuan (2) petunjuk belajar, meliputi petunjuk untuk peserta didik dan guru, (3) isi materi pembelajaran, (4) informasi pendukung, (5) latihan-latihan, lembar kerja, (6) penilaian, (7) respon/balikan/refleksi.

Berdasarkan paparan di atas, dapat disimpulkan bahan ajar memuat judul, mata pelajaran, kompetensi inti, kompetensi dasar, indikator, tujuan pembelajaran, petunjuk belajar (petunjuk guru dan peserta didik), berisi tentang penjelasan cara penggunaan suatu bahan ajar yang akan dipelajari dalam sebuah proses pembelajaran, informasi pendukung, lembar kerja, dan evaluasi.

Menulis sebagai suatu keterampilan berbahasa merupakan kegiatan yang kompleks karena penulis dituntut untuk dapat menyusun dan mengorganisasikan isi tulisannya serta menuangkannya dalam formulasi ragam bahasa dan pesan melalui bahasa tulis. Menurut Abidin (2012:181) "Menulis adalah sebuah proses berkomunikasi secara tidak langsung antara penulis dengan pembacanya. Sebuah tulisan dibuat untuk dipahami maksud dan tujuannya sehingga proses yang dilakukan penulis tidaklah sia-sia”.
Dilihat dari pada bentuk kongkretnya menurut Tarigan (2008:3) "Menulis merupakan suatu keterampilan berbahasa yang dipergunakan untuk berkomunikasi secara tidak langsung, tidak secara tatap muka dengan orang lain”. Sejalan dengan ini, menurut Semi (2007:14) "Menulis adalah suatu proses kreatif memindahkan gagasan ke dalam lambang-lambang tulisan". Senada dengan pendapat di atas Abbas (2006:125) "Keterampilan menulis adalah keterampilan mengungkapkan gagasan, pendapat, dan perasaan kepada pihak lain dengan melalu bahasa tulis".

Berdasarkan pendapat ahli di atas, dapat disimpulkan bahwa menulis adalah suatu kegiatan komunikasi atau aktivitas dari seseorang penulis untuk menyampaikan pesan secara tidak langsung berdasarkan gagasan yang dimiliki penulis kepada pembaca.

Abidin (2012:187) mengemukakan bahwa "Ada tiga tujuan utama menulis yaitu menumbuhkan kecintaan menulis pada diri peserta didik, mengembangkan kemampuan menulis peserta didik, dan membina jiwa kreatifitas para peserta didik yang menulis".

Kemudian lebih lanjut Semi (2007:14) memaparkan "tujuan menulis adalah (1) untuk menceritakan sesuatu, (2) untuk memberikan petunjuk dan pengarahan, (3) untuk menjelaskan sesuatu, (4) untuk meyakinkan, dan (5) untuk merangkum".

Berdasarkan paparan tentang tujuan menulis yang telah di kemukakan dapat disimpulkan bahwa secara umum menulis bertujuan untuk menyampaikan suatu gagasan secara tidak langsung kepada orang lain atau pembaca. Tujuan menulis 
secara khusus dapat dilihat dari jenis menulis yang digunakan dalam menulis.

Hasil belajar yang diperoleh oleh siswa dibandingkan dengan Kriteria Ketuntasan Minimal (KKM) yang telah ditetapkan oleh sekolah. Jika siswa memperoleh nilai sama atau melebihi KKM, maka siswa tersebut dikatakan telah tuntas dalam belajar. Sebaliknya, jika kurang dari KKM maka siswa tersebut tuntas belajar. Pengembangan bahan ajar keterampilan menulis narasi dengan menggunakan Mind Mapping pada pembelajaran tematik di kelas V SD pada pembelajaran tema 8 sub tema 1 ini dikatakan efektif jika lebih dari $75 \%$ siswa mendapatkan nilai $\geq \mathrm{KKM}$.

\section{HASIL DAN PEMBAHASAN}

Menulis narasi merupakan salah satu bentuk keterampilan menulis yang harus dimiliki oleh siswa. Tidak semua siswa mampu menulis narasi dengan baik, sehingga kemampuan siswa dalam menulis narasi sangat rendah. Namun, kemampuan menulis siswa yang rendah dapat ditingkatkan oleh guru dengan cara membuat bahan ajar yang sesuai dengan kebutuhan guru dalam proses pembelajaran menganai materi menulis narasi dengan menggunakan teknik pembelajaran.

Salah satu teknik pembelajaran yang digunakan untuk pembelajaran menulis adalah teknik Mind Mapping (peta pikiran) yang ditemukan oleh Tony Buzan. Konsep ini didasarkan pada cara kerja otak kita menyimpan informasi. Hasil penelitian menunjukkan bahwa otak kita tidak menyimpan informasi dalam kotak-kotak sel saraf yang terjejer rapi. Melainkan dikumpulkan pada sel- sel saraf yang bercabang-cabang yang apabila dilihat sekilas akan tampak seperti cabang-cabang pohon.

Selain itu untuk penilaian dalam penelitian ini adalah penilaian pembelajaran menulis yang disesuaikan antara KD pembelajaran keterampilan menulis yang dipilih dengan tahap pembelajaran menulis yaitu tahap pramenulis, menulis, dan pasca menulis.

Pada tahap pramenulis aspek yang dinilai yaitu hasil pengamatan peserta didik terhadap terhadap teks narasi yang telah dibaca untuk menunjukkan pengetahuan peserta didik terhadap isi teks narasi. Hasil pengamatan dituliskan dengan lengkap dan pertanyaan-pertanyaan tentang apa, dimana, kapan, siapa, mengapa, dan bagaimana telah ditulis dan dijawab dengan benar oleh peserta didik. Kemudian lanjut pada tahap menulis, aspek yang dinilai peserta didik menuliskan informasi penting dari teks narasi dan kemampuan peserta didik dalam membuat Mind Mapping berdasarkan informasi penting yang sudah diperoleh dari teks narasi yang telah dibaca. Hasilnya Mind Mapping yang dibuat telah benar, sistematis, jelas, dan menunjukkan keterampilan penulisan yang baik. Lalu, pada tahap pascamenulis aspek yang dinilai adalah ketepatan peserta didik dalam merevisi, mengedit dan mempublikasikan hasil Mind Mapping yang telah dibuat. Penilaian tahap ini fokus kepada kegiatan publikasi dimana penjelasan tentang hasil mind mapping harus mudah dipahami, pemilihan katanya harus sesuai dengan bahasa Indonesia yang baku. Peserta didik telah mampu untuk mempublikasikannya baik itu secara langsung kepada teman sekelasnya ataupun guru. 
Hasil yang didapatkan dari pembuatan bahan ajar yang dibuat oleh guru sesuai dengan kebutuhan peserta didik dengan menggunakan teknik mind mapping yang juga dapat menunjang keterampilan peserta didik meningkat. Hal ini terbukti bahwa bahan ajar yang digunakan jika disandingkan dengan sebuah teknik yang sesuai dapat memberikan peserta didik pengalaman belajar yang meningkatkan keterampilan peserta didik terhadap sebuah materi pembelajaran yang harus dikuasai oleh peserta didik.

Penelitian yang berkaitan dengan mengenai Mind Mapping yang penah dilakukan yaitu penelitian Ratih, M dan Taufina. (2019), tentang peningkatan keterampilan menulis puisi menggunakan teknik Mind Mapping di kelas V SD. Penelitian Dimas, dkk (2016), tentang penelitian pengembangan media pembelajaran tematik berbasis Mind Mapping SD Kabupaten Ngada Flores. Penelitian Dina, dkk (2019), tentang pelitian tentang pengaruh teknik Mind Mapping terhadap keterampilan menulis puisi siswa kelas Sekolah Dasar. Penelitian Mariana, dkk (2018) tentang penelitian pengembangan buku saku berbasis Mind Mapping pada pembelajaran IPA.

Penelitian Enik (2017), tentang Implementaasi metode Mind Mapping untuk meningkatkan kemampuan menulis cerita pada siswa kelas IV SDN Sumurgung. Penelitian Ratri (2016), tentang peningkatan karakter tanggung jawab siswa SD melalui penilaian produk pada pembelajaran Mind Mapping. Penelitian Mariyana, dkk (2013), tentang pengaruh implementasi strategi Mind Mapping terhadap prestasi belajar menulis kreatif ditinjau dari kreativitas siswa. Penelitain lainnya yang berkaitan dengan Mind Mapping yaitu, penelitian, (Anandita, Sumardi 2018.) penelitian, (Ria. 2016), penelitian (Yosephin, Henny. 2019), penelitian (Darmayoga dan Lasmawan. 2013), dan penelitian (Ayu dan Zulkifli. 2014). Kesimpulan dari penelitian ini menunjukan bahwa pengguunaan teknik Mind Mapping telah melalui tahap uji kelayakan. Hasil uji kelayakan menyatakan bahwa teknik Mind Mapping valid dan reliabel untuk dimanfaatkan secara menyeluruh dalam pembelajaran tematik terpadu di sekolah dasar.

Berdasarkan uaraian diatas maka dapat disimpilkan bahwa kemampuan menulis peserta didik yang rendah dapat ditingkatkan dengan cara membuat bahan ajar sesuai dengan kebutuhan peserta didik yang dibantu dengan penggunaan teknik pembelajaran. Salah satu teknik pembelajaran yang sesuai dengan keterampilan menulis narasi bagi peserta didik adalah teknik mind mapping. Dimana teknik mind mapping ini adalah teknik yang menggambarkan pola-pola dan kemudian dicerna oleh peserta didik sehingga ia mampu mengembangkannya kedalam bentuk tulisan narasi. Selain peserta didik mampu untuk mengembangkannya kedalam bentuk tulisan narasi, mereka juga mampu untuk mempublikasikan hasil tulisan tersebut.

\section{KESIMPULAN}

Bahan ajar merupakan sebuah sumber belajar yang digunakan dalam proses pembelajaran. Penggunaan bahan ajar sesuai dengan kebutuhan dapat menunjang meningkatnya keterampilan peserta didik. Salah satunya adalah keterampilan menulis. Keterampilan menulis peserta didik yang masih rendah dapat ditingkatkan dengan bahan ajar 
yang dibuat oelh guru, bahan ajar tersebut ditunjang dengan penggunaan teknik pembelajaran yang menjadi bagian terbaru bagi peserta didik dalam proses pembelajaran. Salah satu teknik pembelajaran yang dapat digunakan guru adalah teknik mind mapping. Teknik ini merupakan teknik yang membuat sebuah pola-pola pemikiran untuk kemudian dikembangkan dan dituangkan kedalam bentuk tulisan narasi sehingga peserta didik mampu membuat sebuah tulisan narasi dengan pola-pola tersebut. Tidak hanya mampu membuat tulisan narasi dengan baik, namun peserta didik juga mampu mempublikasikannya baik secara langsung maupun didalam bentuk tulisan, sehingga keterampilan meulis peserta didik dalam membuat tulisan narasi yang rendah menjadi meningkat.

\section{REFERENSI}

Ardipal musik, seni, di smp, dan negeri padang, "penerapan model cooperativ learning terhadap aktivitas belajar siswa di smp negeri 1 padang," 2013, 53-60

Abdul, Majid. 2004. Perencanaan Pembelajaran Mengembangkan Standar Kompetensi Guru. Bandung: PT Remaja Rosdakarya.

Abidin, Yunus. 2012. Pembelajaran Bahasa Berbasis Pendidikan Karakter. Bandung: Refika Aditama.

Adalet Baris Gunersel dan Nancy Simpson. 2009. Improvement in Writing and Reviewing Skills with Calibrated Peer Review. International Journal for the Scholarship of Teaching and Learning. Vol. 3, No. 2, Art. 15.

Adiguna, dkk. (2014) Pengaruh Model Pembelajaran Accelerated Learning Mind Mapping terhadap hasil belajar IPA Siswa Kelas V SD No. 2 Tuban. Jurnal Mimbar PGSD Universitas Pendidikan Ganesha Jurusan PGSD (Vol: 2 No: 1 Tahun 2014.
Allen, K.Eillen. 2008. Profil Perkembangan Anak. Jakarta: Indeks.

Buzan, Tony. 2007. Buku Pintar Mind Map untuk Anak. Jakarta:PT Gramedia Pustaka Utama.

Buzan, Tony. 2008. Buku Pintar Mind Map untuk Anak Agar Anak Lulus Ujian dengan Nilai Bagus. Jakarta:PT Gramedia Pustaka Utama.

Buzan, Tony. 2009. Buku Pintar Mind Map. Jakarta:PT Gramedia Pustaka Utama.

Daryanto \& Dwicahyono. 2014. Pengembangan Perangkat Pembelajaran (Silabus, RPP, $P B H$, Bahan Ajar). Yogyakarta: Gva Media.

Purwanto, Ngalim. 2011. Prinsip-prinsip dan Teknik Evaluasi Pengajaran. Bandung: PT Reamaja Rosdakarya.

Ratih, M dan Taufina. (2019). Peningkatan Keterampilan Menulis Puisi Menggunakan Teknik Mind Mapping di Kelas V SD. JINoP (Jurnal Inovasi Pembelajaran), Volume 5, Nomor 2, November 2019 P-ISSN 2443-1591 E-ISSN 2460-0873

Ratih, M dan Taufina. (2019). Pengembangan bahan ajarmembaca permulaan dalam pembelajaran tematik dengan model vark (visual, auditory, read/write and kinesthethic).JP2SD (Jurnal Pemikiran dan Pengembangan Sekolah Dasar) Vol. 7, No. 2, September 2019 Hlm. 82-90 p-ISSN: 23381140, e-ISSN: 2527-3043 // http://ejournal.umm.ac.id/index.php/jp2sd

Sadhono, Kundharu dan St. Y. Slamet. 2012. Meningkatkan Keterampilan Berbahasa Indonesia. Bandung: Karya Putra Darwati.

Setyosari, Punaji. 2010. Metode Penelitian Pendidikan dan Pengembangan. Jakarta: Kencana.

Husada, Syahda Puspita, Taufina, dan Ahmad Zikri (2020). Pengembangan Bahan AjarPembelajaran Tematik dengan Menggunakan Metode Visual Storytelling di Sekolah Dasar. Jurnal BasiceduVolume 4Nomor 2 April 2020 Hal. 419-425 
847 Pengembangan Bahan Ajar Keterampilan Menulis Narasi Dengan Menggunakan Mind Mapping Dalam Pembelajaran Tematik Di Sekolah Dasar - Eliyanti, Taufina, Ramalis Hakim

DOI: 10.31004/basicedu.v4i4.439

Taufik, Taufina dan Muhammadi. 2011. Mozaik

Pembelajaran Inovatif. Padang:

Sukabina Press.

Tarigan, Henry Guntur. 2008. Menulis sebagai suatu Keterampilan Berbahasa. Bandung: Angkasa.

Trianto. 2009. Model-Model Pembelajaran Inovatif Berorientasi Konstruktifistik Jakarta: Prestasi Pustaka.

Trianto. 2011. Pengantar Penelitian Pendidikan bagi Pengembangan Profesi Pendidikan dan Tenaga Kependidikan. Jakarta:Kencana. 